\title{
Protection Versus Flexibility: The Civil Service Reform Act, Com- peting Administrative Doctrines, and the Roots of Contemporary Public Management Debate
}

The year 2003 marks the twentieth-fifth anniversary of the Civil Service Reform Act (CSRA) of 1978, a late chapter in the development of the American administrative state and the most significant reform of the civil service system since its creation through the Pendleton Act of 1883. The Act made a number of enduring contributions to the personnel system of the federal government. Given the recursive nature of public management debate, there is considerable policy importance in trying to understand the original basis of decisions on legislation that have shaped the federal government over the last twenty-five years, and the CSRA has recently been the subject of renewed interest. ${ }^{1}$ More important, the CSRA was a rare and relatively important shift in the beliefs and attitudes-the administrative doctrine-that shape the evolution of the administrative state. ${ }^{2}$ Significantly, the debate during the CSRA saw the emergence of deep divisions within administrative doctrine, divisions that continue to shape public management policymaking.

Management experts battled with each other to establish a dominant model for the civil service. On one side, traditionalists defended the protection doctrine, arguing that neutral competence could only be maintained by a civil service system that protected employees from undue political influence. On the other side, reformers established the new flexibility doctrine, arguing to create incentives for performance and responsiveness to political leaders. The flexibility doctrine drew on private-sector models of management, which was

THE JOURNAL OF POLICY HISTORY, Vol. 16, No. 1, 2004.

Copyright (C 2004 The Pennsylvania State University, University Park, PA. 
far from unusual in public management debate. What was unusual was that the flexibility doctrine, by emphasizing managerial discretion and control as desirable management practices, offered the first serious and direct challenge to the protection doctrine and the idea that protection of employees was necessary to good management and competent performance. Further, and most troubling for protection advocates, flexibility advocates simultaneously relied on performance and political responsiveness as equally valid and closely connected justifications for reform. Protection advocates feared increased politicization of the bureaucracy as the inevitable result.

These battle lines in administrative doctrine became more pronounced after 1978 and continue to shape the existing public-management policy debate. In the last quarter century, the flexibility doctrine has gained ground. Former Vice President Al Gore led the National Performance Review (NPR) for the duration of the Clinton administration, arguing for greater managerial flexibility, reduced red tape, and a focus on results. ${ }^{3}$ President George W. Bush's management agenda is similarly performance-oriented. ${ }^{4}$ His ultimately successful demands for management flexibility, particularly changes to specific provisions of the CSRA on bargaining rights, stalled legislation creating the massive Department of Homeland Security in months of acrimonious Senate debate. The contemporary public management debate sees presidents and reformers reargue the intentions, implementation, and limits of the CSRA. The basic concepts that decision-makers wrestled with in 1978-merit, performance, politicization, flexibility, and responsiveness-remain defining tensions. ${ }^{5}$

In addition to mapping out the battle lines in administrative doctrine, the CSRA also established the pattern of engagement. In 1978 reformers failed to radically change the civil service system, but instead settled for incremental change. This pattern has recurred, as the rise of the flexibility doctrine has resulted only in partial reform of the civil service system. Over time, the civil service system became an institution difficult to change, effectively defended by public service unions. While flexibility proponents hope to dramatically change government-wide personnel rules, their rare attempts to do so have failed. Instead, reformers have chipped away at the system in piecemeal fashion, achieving a gradual shift toward flexibility through a combination of executive orders, personnel legislation for specific agencies, or provision of experimental flexibility for parts of government. ${ }^{6}$ As a result, the different parts of the present 
federal public sector, to varying degrees, reflect both the continuing legacy of the protection doctrine and the growing influence of the flexibility doctrine.

As with other accounts of the development of the administrative state, the CSRA reflects the recurring themes of the interplay of politics and administrative doctrine, the fight for political control of the bureaucracy, the strength of existing political institutions, and the unanticipated consequences of reform. ${ }^{7}$ The CSRA also provides an understanding into the way in which politicians seek to design public institutions. While noting the importance that the various schools of the new institutionalism assign to the role of the public sector in creating and enforcing rules for society, B. Guy Peters laments the limited empirical investigation into the creation and design of public institutions. ${ }^{8}$ How are these public rules designed, and what are the intents and motivations of the designers? The CSRA provides a specific case study of the reform of a core public institution, the civil service system.

In addition to previous analyses of the CSRA, ${ }^{9}$ this article draws on interview transcripts from an oral history of the CSRA made available by the Alan K. Campbell Public Affairs Institute at Syracuse University. Key actors involved in the CSRA were interviewed, including members of Congress, high-level political appointees, representatives of unions, and other interest groups and journalists. Interviewees are listed in Appendix 1, which also provides interview numbers that will be cited to specify sources. Source citation will also include the interview transcript page number. The interviews prompt these figures to analyze their public role, how they process information, devise strategies, and make decisions. At a general level, this analysis therefore offers a qualitative perspective of the process of policymaking in Congress, adding to the relatively few social-scientific studies based on rich, in-depth interviews from a range of policymakers, done in the immediate aftermath of a major piece of legislation. ${ }^{10}$ Interviews were completed in 1979 , a year after the bill had been passed, by interviewers from the National Academy of Public Administration (NAPA). The transcripts were content-analyzed using a qualitative software package called QSR Nudist. ${ }^{11}$ 


\section{What the CSRA Achieved}

Before analyzing the politics and competing doctrines behind the CSRA, it is helpful to outline its legislative outcomes. Table 1 summarizes the changes the CSRA made to existing statute, some of which reflected a protection approach and some a flexibility approach.

Merit Principles: The idea of merit was always an explicit part of the civil service system, but just what merit actually meant had never been clearly defined in law. Title I of the CSRA enumerated the following as principles of merit: diversity, talent, fair treatment of employees, equality of reward, integrity, efficiency, adequate performance, protection from adverse action for partisan political reasons, and protection for whistleblowers.

The Office of Personnel Management and Merit Systems Protection Board: The CSRA eliminated the Civil Service Commission (CSC), which had struggled to balance a dual mission of advising the president on personnel matters and ensuring fair treatment of federal employees. The dual mission was divided between two newly created agencies. The Office of Personnel Management (OPM) became the president's adviser on personnel policy and the Merit Systems Protection Board (MSPB) safeguarded employees from unfair treatment. The Director of the OPM was a presidential appointee with a four-year term. The MSPB was more independent. Three presidential appointees held seven-year terms, with removal only for inefficiency, neglect of duty, or malfeasance.

The Senior Executive Service: Title IV created the Senior Executive Service (SES). The SES would set distinct personnel rules for senior managers (defined as employees above 15 on the General Schedule) and could include no more than 10 percent political appointees. Pay increases would be based on performance, not seniority, and would amount to up to 20 percent of the base salary, although the size of bonuses would later be reduced by the OPM. By tying rank to person, not position, the SES was intended to encourage high mobility between different parts of government, since employees did not have to fear downgrades from reassignment. Supervisors of SES members were granted authority to reassign, although they were cautioned that this power should not be used for partisan political purposes.

Veteran Preference: Carter's White House argued that veteran preference in federal personnel hiring and reductions-in-force procedures reduced management flexibility in using human resources 
DONALD P. MOYNIHAN

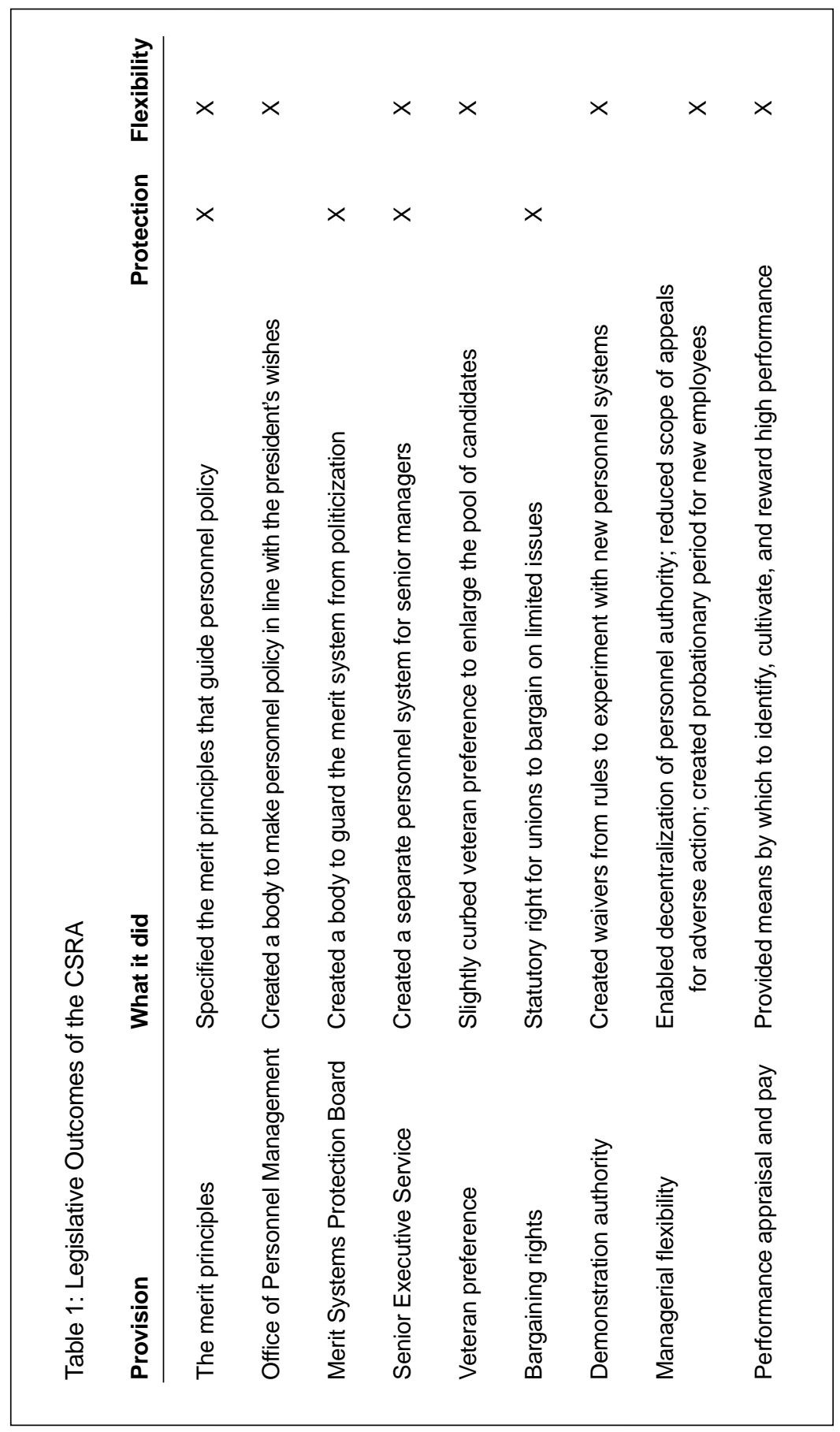


and negatively affected women and minorities, who were less likely to be veterans. The CSRA curtailed the practice of veteran preference to those who retired below the rank of Major or Lieutenant Commander. Congress rejected a more extensive White House proposal to reduce to ten years after army service the amount of time any nondisabled veterans would receive preference in hiring and to three years in reductions-in-force decisions.

Bargaining Rights: A 1962 Executive Order enabled collective bargaining between federal management and unions, although not on salaries and benefits. Title VII codified this order into statute but allowed the president to exempt employees for national security reasons. Title VII also created the Federal Labor Relations Authority, made up of three five-year presidential appointees, with the consent of the Senate, to oversee bargaining and other personnel disputes.

Demonstration Authority: Title VI enabled the OPM to waive federal rules to allow agencies to experiment with personnel innovations. The experiments were to be evaluated by the OPM in order to learn lessons that might be applied to the rest of the government.

Managerial Flexibility: Title II allowed the director of the OPM to delegate his powers to agency heads. This included preparing and administering competitive exams to candidates, but only for positions unique to the agency. White House proposals to expand the hiring selection pool offered to managers from three to seven were rejected. Title II also attempted to make dismissal of employees easier by narrowing the basis for employee appeal in cases of adverse action to substantive procedural error, racial discrimination, or arbitrary or capricious action. To a much greater extent than before, the burden of proof lay with the employee rather than the employer. To allow supervisors to assess the suitability of a candidate, Title III made appointments, promotions, and reassignments subject to a probationary period before they became permanent.

Performance Appraisal and Pay-for-Performance: Title II decreed that under the direction of the OPM each agency was to develop an appraisal system that ranked the employee in terms of clear performance standards. Such information would inform decisions of training, rewarding, reassigning, promoting, and demoting, and if performance was ranked as unacceptable, firing the employee. Title $\mathrm{V}$ created a pay-for-performance system for mid-level employees, where employees could expect that a significant portion of pay would be tied to performance appraisals. 


\section{The Administrative State and the Protection Doctrine}

Unlike European counterparts, the civil service system in the United States came after the establishment of a national democracy. By the time the Pendleton Act was passed in 1883, political parties were the dominant institutional force that shaped how government worked, using administrative appointments for patronage purposes. ${ }^{12}$ As the challenges facing the federal government grew, the need for competent administration became clear. The spoils system had come under public attack for its perceived moral and practical failings, and the parties accepted the need for the civil service reforms championed by the Progressives. Progressives outlined the basic elements of a new administrative doctrine, borrowed from European civil service systems. This doctrine called for limited political influence in administration; emphasizing competence and qualification in selection, guaranteed by competitive exams; employee protection from firing and other adverse action based on political reasons; and predictability in pay and promotion. Progressives argued that in the context of a spoils system that bred corruption and incompetence, such changes would inevitably lead to a more professional and higher-performing civil service. ${ }^{13}$

The Pendleton Act represented a break with the past, although the civil service system in the United States continued to bear the imprint of what had gone before. While the new system was based on the idea of merit, political parties continued to use it adeptly. The civil service system was only gradually extended throughout government, allowing the practice of patronage for decades to come, while ensuring a degree of administrative continuity and competence necessary for the expanded role of the state. The ongoing imprint of the spoils era was clearest for senior management. By reserving senior-level managerial positions for political appointees, lateral entry and explicit political responsiveness would remain a characteristic of the U.S. civil service.

The origin and implementation of the civil service system was shaped by party needs, but did signal the adoption of a new way of thinking about how the public service should be run: the protection doctrine. Throughout the twentieth century a number of public management reforms were proposed, but until the CSRA none seriously challenged the basic elements of the protection doctrine. While other management principles would come under attack, the basic idea of maintaining competence through rule-based protections of 
employees remained..$^{14}$ In part, this was because parties still enjoyed ample opportunities for patronage, and exerted political control over the increasingly protected bureaucracy through increased use of political appointments. ${ }^{15}$ At the same time, public administration experts did not seriously question the performance of the traditional bureaucracy, whose logic of rational neutral expertise was reinforced as translations of Max Weber's writings were widely distributed after World War II. ${ }^{16}$

\section{Competing Administrative Doctrines}

What was the rationale behind the move to reform the civil service? The CSRA was not sparked by any single incident, or designed to prevent an impending crisis. However, the Nixon administration had been accused of personnel abuses, using political influence in the appointment and control of positions, aimed at exerting a strong presidential dominance of the bureaucracy. Many interviewees refer to the infamous Malek Manual, a guide for Nixon political appointees about how to work around civil service rules to install political supporters within the bureaucracy. The accusations led to an investigation by the CSC, resulting in the Sharon Report, which confirmed systemic evasion of the system, and counter accusations that the Commission knew about and was complicit in these practices. ${ }^{17}$ Public unions, Common Cause, ${ }^{18}$ many senior civil servants, and some Democratic Congressmen interpreted the Nixon period in two ways. First, the merit system had shown its worth by enabling continuity of government service throughout the Watergate crisis (\#1, $24 ; \# 11,10)$. Second, the personnel abuses under Nixon demonstrated the need for more vigorous protections to safeguard the merit system (\#2-2 64-74; \#6, 9; \#11, 5; \#20, 3; \#30, 4-5). Protection advocates won some victories in the CSRA, including enhanced whistleblower protections, statutory bargaining rights, and caveats forbidding politically motivated or arbitrary adverse action in the merit principles and SES sections of the law.

However, while protection advocates created momentum for reform, the main source of change came from the flexibility doctrine, a very different approach to administration. The flexibility doctrine characterized the civil service system as outdated. While the competence created through protection had once raised performance, the continued growth of rules now limited management ac- 
tions that would improve performance, limiting productivity and effectiveness (\#2-1,35; \#4, 4; \#21,8). The flexibility doctrine portrayed the system as rule-bound, centralized, and lacking incentives for better performance. The antidote to entrenched employee protections was to grant managers more flexibility-meaning more management discretion, less rigid personnel rules, less interference from the central agencies, an ability to hire and move employees around, and promote or discipline employees as the situation demanded. Such flexibility ran counter to the protection doctrine, since more discretion meant greater potential for the use of that discretion in ways inconsistent with a merit-based civil service. Most flexibility advocates acknowledged the need for some employee protections, but felt that "the system had tipped much too far in the direction of employee protections" (\#2-3, 16). ${ }^{19}$

\section{Warrants Within the Flexibility Doctrine: Performance and Responsiveness}

Supporters of the flexibility doctrine-the Business Roundtable, political appointees, representatives from both parties, and administration proponents of the legislation-were simultaneously motivated by two distinct concepts: performance and responsiveness.

The performance concept arose from a belief that the neutral competence created by the spoils system was no longer an adequate standard for the public sector. Individuals needed to be held accountable for performance. The CSRA is the first legislation cementing the idea and language of public-sector "performance" into civil service personnel law, in terms of improving, tracking, and rewarding individual achievement, a marked departure from the rule-based format of civil service law. The CSRA linked performance actions (disciplining or firing people on the basis of inadequate performance), performance appraisals (supervisor assessment of employee performance), and performance-related pay to the individual bureaucrat. Carter's appointee as head of the CSC, and the most visible administration spokesperson for reform, Alan "Scotty" Campbell, saw the CSRA as a shift in managing the civil service: "To the extent the legislation represents a basic new direction for the public personnel management field, it does so by moving attention away from what has almost been the exclusive attention of the public personnel field, 
which has been selection of people, to a much broader concern with performance of people once in the workforce" $(\# 2-3,59)$.

It could be argued that previous reform efforts that discussed efficiency, reorganization, or principles of management were in fact also concerned with the idea of performance, but had simply used different language. ${ }^{21}$ However, previous reforms had not cast the protection doctrine as an obstacle to performance. It was not until the establishment of the CSRA that we saw a management doctrine that assumes that personnel flexibility is the key to improving performance, and that the protection-inspired rules of the civil service reduce performance.

Performance became closely aligned with the idea of responsiveness, based on a shared presumption that bureaucrats were unable-or unwilling - to perform well, and executives needed substantial discretion and flexibility to manage. The responsiveness perspective defined performance in terms of the ability to implement the changes requested by political leadership. While campaigning, Carter argued that political officials had a right to more responsiveness from bureaucrats who had grown immune to any prodding for change. George Maharay, a consultant with the National Academy of Public Administration, notes: "An incoming manager, or political appointee, one, wants many times to bring in some of his own people, and two, wants to be able to move people around. Under the old system it was almost impossible to do it. And that has been a very, very sore point for every administrator who's ever come into this government" $(\# 21,8)$.

Whereas the concept of political responsiveness had once been associated with the incompetence of the spoils system, it now appeared consistent with arguments for better performance and the success of the private-sector organizations. Responsiveness now found renewed justification and legitimacy in the context of an administrative doctrine that promised performance, a more socially acceptable goal than simply political control. The CRSA enhanced responsiveness through the ability to make 10 percent of all SES positions political appointees. Responsiveness was also improved through the creation of the OPM, the power of the president to appoint the director of the OPM, and the powers that the director wielded over the personnel system and its employees in the name of the president. The flexibility that managers required for better performance-the ability to choose a team of employees and reassign them-could also be used by political appointees to ensure respon- 
siveness for politically defined goals. Responsiveness was one of the elements of the CSRA that was particularly attractive to Republicans. Theodore Kazy, a staff member on the Republican side of the House Post Office and Civil Service Committee, explains how expanded political control of the bureaucracy encouraged Republicans to support Carter's reform:

It would have been hypocritical to say that it's a good system to have patronage appointments, people that you not only hire but also fire, at the higher level, under a Republican administration but not under a Democratic administration. If we're going to enact it under a Carter administration, then we have to look down the line and say that we will probably inherit this within four years anyway if we play our cards right, so what we're enacting is something that the Republican administration at some time will be able to use just as well. $(\# 15,8)$

In the rhetoric of the time, and in subsequent interviews, it becomes clear that flexibility advocates did not distinguish differences between the concepts of performance and responsiveness and viewed them as interchangeable $(\# 2-2,1 ; \# 4,2,11 ; \# 6,2 ; \# 7,15)$. This was exactly what the protection advocates feared, claiming that wellintentioned reforms in the name of performance would, sooner or later, be used for partisan political control (\#11, 4; 22, 1-2). The dark side of responsiveness was the partisan politicization that the civil service system was designed to prevent.

\section{The Role of Carter and White House Strategies}

The wider policymaking context provides some additional insights into momentum for the CSRA. The post-Watergate era saw a decline of confidence and trust, particularly in government, and the rise of public-interest-group influence in policymaking. ${ }^{22}$ At the same time, economic woes directed attention toward uncontrollable government spending and productivity. Both factors increased President Carter's willingness to champion a civil service reform that cut waste, created a more efficient public sector, and helped balance the budget. $^{23}$

Carter had campaigned on the issue of reforming the "Washington marshmallow" that was the bureaucracy, and he maintained 
an active role in the legislative process. ${ }^{24}$ The circumstances of the CSRA suggest that this was an issue particularly amenable to presidential involvement. Democrats held the White House and Congress, and the president sought support for what was characterized as a matter of internal management of the executive branch. White House staff welcomed the bill not just because it was consistent with Carter campaign themes, but also because they were desperately seeking a legislative victory on the domestic policy agenda $(\# 3,19 ; \# 7$, $16-17$; 25 22). Jule Sugarman, a political appointee at the CSC, recounts that by the end of 1977 "the President was in a lot of political trouble and his staff was very concerned about what to do; and then they became aware of civil service reform. Although they really didn't know too much about it, it looked like a winning issue to them. So, all sorts of people were mobilized behind civil service reform" $(\# 30,17)$.

Civil service reform competed with other policy matters for attention, and making the CSRA a presidential policy priority was a necessary precursor for a credible legislative proposal to emerge from the administration. One of Campbell's main achievements was convincing the President to make and maintain civil service reform as a priority. Andrew Feinstein of Public Citizens Congress Watch notes: "OK, what Scotty Campbell accomplished was he had the grand vision of what this was supposed to look like, and he convinced the President to take an active role in it" $(\# 5,4)$. Presidential support gave Campbell leverage within the executive branch. It prompted the creation of the President's Personnel Management Project (PMP), a task force charged with analyzing the civil service system, announced in June 1977. The PMP was largely staffed by civil servants, and the President's support allowed Campbell to persuade agency heads to release key employees to work on the PMP $(\# 2-1,16)$. Cabinet members were also convinced to lobby members of their legislative oversight committees on the benefits of the CSRA $(\# 11,10)$.

In terms of actual activities, the President was involved in a number of ways. He was involved in early meetings on content and strategy, expressing preferences between options presented, and was kept up to date on changes in the legislative process $(\# 2-2,2 ; \# 13$, $12 ; \# 30,11,38)$. The President could also intervene at critical junctures in the process. There are numerous examples of the President's personal intervention to persuade key actors in the legislative branch to do what was necessary to push the policy process along $(17, \# 13$; $\# 22,2)$. The most critical intervention occurred when Carter per- 
suaded presidential primary rival, Morris Udall (D-Ariz.), to lead the bill in the House $(\# 2-2,7 ; \# 14,32)$.

In proposing reform, the White House took a mixture of purposeful planning and a strategic approach that evolved with the legislative process. Aspects of the preconceived strategy were to make the legislation a presidential priority; to give the bill bipartisan appeal; to generate a large amount of press support, particularly in the form of editorials; to utilize as broad a support of interest groups as possible and to make this support as committed as possible; to gain union support or at least neutralize opposition, preferably that of the biggest union, the AFGE; and to generate recommendations and credibility through the PMP (\#2-1, 27, 44; \#7, 1-4, 13; \#30, 7, 11). Some of the more evolutionary aspects of strategy were to generate momentum in the friendlier Senate to pressure the House; involve Udall as the legislative leader and main legislative tactician; make Campbell the main administration spokesperson and negotiator; use Cabinet members to lobby their oversight committees; and to threaten veto if the bill was judged to be turning too pro-labor ( $\# 2$ $2,8,23 ; \# 17,17,20-21)$. Each of these strategies could be analyzed in their own right, as could the strategic approaches employed by other actors. However, it is sufficient to note that the overall strategy was a mixture of the preconceived and the evolving, with the evolving aspect usually employed to deal with a specific problem that arose out of errors of omission, or just errors, of the preconceived aspect.

One strategy that is worth noting is the attempt to use public discontent with the bureaucracy to generate momentum for a reform that purported to deal with these concerns. Howard Messner, of the Office of Management and Budget, comments:

It's [the bill] very hard to read. I mean, you have to be a student of it. The public liked the themes; we developed these themes like incentives, you know, that were understandable. And our polls. We had done some polls and Gallup had done polls that showed the public generally felt that federal employees had a different workplace than they had. They didn't care for that. They didn't understand why that would be, and there were hostile stories about federal employees being overpaid and under-worked and most of them prejudicial. It left a very bad taste in the public's mouth. Civil service reform was perceived as a way to deal with those problems $(\# 23,40)$. 
James P. Mooney, from the Office of the Majority Whip of the House of Representatives, notes the impact this public discontent had in garnering congressional support: "Well, you can add it to the good things that you voted for. I think that the public seems generally hostile to the career bureaucracy, and to the extent that you could say you helped to reform the career bureaucracy by voting for Civil Service Reform-I suppose that's a plus" $(\# 24,15)$.

\section{The Knowledge Basis for Doctrinal Arguments}

Public management doctrines are practical theories of politics, employing arguments based on managerial principles and democratic values-rather than social science-and are usually expressed in a rhetorical style. ${ }^{25}$ In the case of the flexibility doctrine, democratic values were represented by the call for greater responsiveness, while managerial principles drew on private-sector practice, public-administration academic advice, and practitioner experience. The PMP did not do original social science research but offered policy options on the basis of the firsthand experience of the members, a review of previous literature and ideas, and a series of meetings with federal workers that were conducted around the country. The recommendations of the PMP therefore summarized existing views. Campbell points out the limitations of this approach: "I was always a bit bothered by this, that we were drawing on a body of knowledge that did not have the kind of research roots with which I am comfortable when I'm dealing with policy issues, and I had occasional doubts myself as to whether we really had the kind of knowledge and depth that we needed to do this job" $(\# 2-1,43)$.

Many of the ideas that underpinned the flexibility doctrine were not new but had simply never found the same level of support or success as they did with the CSRA. Some of the White House proposals had an impressive vintage, drawing from previous management congressional commissions (for example, the Brownlow Commission of 1937 and the Hoover Commissions of 1949 and 1955) and failed legislative efforts $(\# 8,1-3 ; \# 16,13)$. Austin Kerby of the American Legion had testified on similar proposals since the late 1950s $(\# 16,1)$, and House member Jim Leach (R-Iowa) regarded the ideas presented to Congress as "anything but novel" $(\# 18,2)$. Jule Sugarman notes: "So, I think, we had a reasonable understanding of everything that had been proposed in the past. As you prob- 
ably know there are no really 'new' ideas in the world; there are only refinements of old ideas that you find" $(\# 30,13)$.

Thomas Murphy, the acting director of the PMP, confirms the role of the PMP as that of collector of previously created information:

We became a mechanism to use studies which people previously had invested time and money in. Those studies were collected that were generally known to the kinds of people we had on the task forces, some of whom had worked on those prior studies, and we went out to check certain kinds of things. If we wanted to make a particular recommendation, for example, we might try to test out the impact of that, but you couldn't do it in a real research way; you did it in a practical way by going to people in the business and finding out what they thought would be the results. So we used informed judgment from a broad variety of people. $(\# 25,19)$

The latter part of the quote also reveals the inherent limitations of PMP knowledge about policy ideas. Potential policy solutions were tested only to the extent that they could be discussed with stakeholders and experts. The role of experts (such as members of National Academy of Public Administration) was to advise the administration and PMP and testify to Congress. In areas where there was enough interest, a special panel might be created, representing the view of academia and practitioner experience.

The knowledge limitations of the CSRA demonstrate a clear example of public management policy being made on the basis of weakly defined theory and, as David Farber of the National Governor's Association points out, a theory that remained unproven. ${ }^{26}$ Of the influences on the CSRA, strong social science research or any form of technical analysis is not cited among interviewees. However, the theory represented by the CSRA remained appealing to decision-makers, especially in the executive branch. Farber comments: "The practical effects, of course, remain to be seen. The theory is clearly that greater opportunities, greater freedom, greater authority, greater potential rewards are to be available to some of the senior managers in the system. It is an appealing theory from the standpoint of chief executives, as I indicated, and I think it will take some careful work" $(\# 4,4)$. 
The lack of strong social science research might imply that the reform process was undersupplied with information. This was not the case. Information was freely available from reformers and opponents of the bill. Congress was provided with extensive written statements and testimony. The PMP itself was a massive effort, with a staff estimated to be over a hundred people. Clearly the executive branch placed a great deal of effort in creating the appearance of a store of knowledge, despite the nonscientific nature of this knowledge. The implication is that such an appearance of knowledge was a necessary precondition for the legislative proposal to have credibility when presented to Congress. ${ }^{27}$ However, it is clear that the rise in the flexibility doctrine was based not on new social science findings but on crafting a mixture of old and new ideas into a coherent practical argument about how to run public organizations.

\section{Congressional Debate: "mile-wide, inch-deep"}

Most members of the Congress had very weak knowledge of, and interest in, the actual contents of the bill. There are a number of reasons for such disinterest. First, the specifics of implementation were generally agreed to be opaque because of the dry complexity of public personnel law. Also, few members were deeply invested in the outcome of the legislation, bar those with a high proportion of federal employees in their district, who fell into the protection camp $(\# 2-2,50)$. The CSRA was therefore a "good government" bill; a type of reform with positive but diffuse benefits for society but without tangible, immediate, or large benefits to most, making it difficult to activate the support of interest groups. Support tended to be broad but with little intensity, what Campbell later referred to as a "mile wide, but an inch deep." ${ }^{8}$ Politicians supported civil service reform because of a high level of popular discontent with bureaucracy. In contrast, the relatively narrow groups directly affected by the CSRA, such as army veterans, federal employees, and unions, had a strong incentive to oppose or reshape the bill. ${ }^{29}$

The mile-wide/inch-deep problem created a particular time factor. Given the number of bills competing for attention, if it appeared that the CSRA was unlikely to pass, its inch-deep supporters saw their marginal gain decline in value relative to gains from passing legislation in other areas. If such bills cannot be passed quickly, their opportunity cost relative to other bills is too high for them to sur- 
vive. This provides the incentive for opponents to block the bill using delaying tactics. Such delaying tactics are most potent at the floor level, where the opportunity cost (based on the time taken of the whole body rather than just committee members) is at its premium. The leadership of each legislative body acts as the referee in calculating the opportunity cost of a bill and deciding whether to table it for discussion. Senate majority leader Robert Byrd refused to allow the bill to the floor unless it was clear that there would be sufficient votes to bring cloture on a filibuster threatened by Senators Charles Mathias (R-Md.) and Stevens (R-Alaska), which was resolved only after a meeting with Carter. ${ }^{30}$

Proposals to reform of the Hatch Act, led by Representative William Clay (D-Mo.), also threatened to delay and derail the CSRA. The Hatch Act of 1939 restricted the political activities of public workers. The reforms proposed by Clay would have guaranteed federal workers increased political freedom. On this issue the protection and flexibility coalitions appeared to switch positions. Clay was supported by the protection coalition, particularly unions, who argued for flexibility in terms of the political activity of nonappointees. The pro-flexibility camp was fiercely opposed to increased political activity - the Republicans because they feared it would advantage the Democrats, and the administration because they feared it would sink the bill. Clay delayed the bill by various tactics such as requesting the lengthy bill be read aloud in session. Clay's efforts resulted in the bill being withdrawn after a single day of debate on its first introduction to the House floor on 11 August 1978, and it was not reconsidered until 8 September, by which point it had been passed in the Senate by a vote of $87-1$ on 24 August. Again, Carter's intervention was necessary. While overseeing Middle East peace negotiations at Camp David, Carter signed a statement reassuring Clay that he would support legislative change to the Hatch Act in another setting.

Clearly, presidential intervention and the administration's willingness to deal and compromise helped to overcome delay to the bill at a critical juncture. Also important was what Sugarman referred to as the "critical mass" aspect of the CSRA- "it was big enough that it demanded attention" $(\# 30,40)$. The old ideas that had not succeeded as individual efforts were put together in a more comprehensive legislative package than before. This helped counter the mile-wide/inch-deep factor, solidifying commitment among supporters who believed that even if the CSRA provided only limited 
political benefits, it was a significant enough change to the public sector to be worth fighting for.

\section{Trust in Key Members}

The lack of interest in, and familiarity with, the content of the legislation meant that most legislators based their decisions on whether or not to support the bill on considerations other than actual content. Party position is an obvious such consideration, as was constituency concerns for the handful with a large number of federal employees in their districts. Such members found it in their interest to seek membership of governmental affairs committees in disproportionate numbers, and usually had proved successful in blocking reform efforts $(\# 7,20 ; \# 8,7 ; \# 14,15-16)$.

Two other decision criteria were important for members in relation to the CSRA. The first was trust in key members; the second was the values represented by the CSRA and underlying flexibility doctrine. Trust in key members was particularly important in the House, which proved a far more difficult and drawn-out battle for Carter than the Senate. The White House realized that the Democratic majority of the House Post Office and Civil Service Committee viewed the reform as too heavily weighted toward managerial flexibility, and that even if Republicans agreed with the bill, they were not predisposed toward helping Carter (\#18, 2-3). Perhaps the best strategic move that Carter and Campbell made was to recruit senior and respected committee members from either party-Udall and Ed Derwinski (R-Ill.) — to actively support and promote the bill. Both men carried enough sway with fellow committee members to ensure the CSRA's passage from success in the House (\#1, 24-26; \#3, 14, 25-26; \#17, 21).

Derwinski persuaded colleagues that the flexibility doctrine was consistent with Republican ideology, and that future Republican administrations would enjoy the benefits $(\# 18,3,8)$. Brooks Jackson, a reporter covering the CSRA, also recounts more idealistic reasons:

When I asked him why he supported this bill, and why he vested so much effort in it, he said it was, of course, the right thing to do and all that, and never mind if it rebounded to the credit of a President of the opposite party; it was still the 
right thing to do, and besides, if I'm recalling his words correctly, he said it's not often that we over here in the House get to be a part of something that's a big national story and is really important. And he had a sense that they were really accomplishing something over there that was important and it was of national interest. $(\# 14,27)$

Udall faced an even trickier job than Derwinski, balancing the competing views of the administration and pro-protection House Democrats. When he agreed to lead the bill, he insisted that the White House not second-guess his legislative strategy. This strategy, dubbed "keeping it fuzzy" by Campbell $(\# 2-2,9)$, was to do what was required to make the bill acceptable at the committee level, by inserting a union-friendly labor-relations title, with the intention of moving it toward the administration position on the House floor and conference committee. In doing so he could entice pro-union committee Democrats to support the legislation, while usually maintaining a coalition of trusting Republicans, led by Derwinski. Derwinski and the White House were opposed to the labor title reported from committee but were relying on Udall's commitment and capacity to modify the bill on the more moderate House floor. Udall delivered, managing the bill on the floor, where most Democrats were content to accept changes he proposed or supported, including his own labor-relations substitute amendment.

\section{Values, Ambiguity, and Compromise}

The flexibility doctrine offered a simplified explanation for what the bill contained and the values it represented: enhancing the performance, responsiveness, and accountability of the bureaucracy. These values were accepted by most legislators as worthwhile, as was any legislation than claimed to promote them. Members chose not to engage in intense debate if they took for granted that legislative language would foster desired values. For instance, merit pay and the Senior Executive Service were radical reforms of the day-to-day management of the civil service sector and administration proponents expected them to be the most controversial of proposals. This was not the case. The White House also won support by convincing legislators that some changes were not radical and were a matter of internal executive branch management. This strategy worked par- 
ticularly well for complex legislative text, but it was dependent on avoiding statements of dissent from key members or committees. An example furnished by Jule Sugarman was the "about 10 seconds of debate" that labor-relations received in the Senate.

The interesting thing about it, of course, is that if you look at the time spent on the bill by Congress, most of that time went into relatively minor issues, and very little time went into the major issues. ... . But, for example, take the labor-relations title ... they called it the "dark continent of the bill," and said that they didn't want to take the time to understand it, so they just passed it. "The President wants it; we'll pass it," attitude. And, you know, it had the air of being conservative, restrained, i.e. no changes from the existing situation. $(\# 30,27)$

The Senate adopted labor-relations language that went even beyond what the administration requested, creating room for compromise in conference with the more union-friendly bill passed in the House. The Senate Governmental Affairs Committee was chaired by Senator Abraham Ribicoff (D-Conn.), with Senator Charles Percy (R-Ill.) as ranking minority member. Both were largely supportive of the CSRA and willing to report it from committee. However, Ribicoff was concerned about the appeals process for federal employees who claimed employer discrimination and whether the MSPB or the Equal Employment Opportunity Commission (EEOC) would have final jurisdiction (\#2-3, 4-12; \#4, 4-9; \#28, 4-5). Ribicoff sided with the MSPB, refusing to pass the bill out of committee until he received assurances that his version would prevail. The House bill gave the EEOC final say, leading to a compromise in conference that involved a byzantine series of multitrack appeals and independent commissions.

Whistle-blowers, employees who reported undesirable activities in the workplace, were another area of contention. Supported by Common Cause and the Senate, in particular Senator Patrick Leahy (D-Vt.), the bill expanded whistle-blower protection to employees who reported not only illegal activity but also other undesirable situations, including waste and mismanagement. While the administration supported limited whistle-blower protections, it was concerned that too much protection provided simply another form of red tape that slowed adverse action rather than improving management. However, Common Cause also found support in the House Com- 
mittee from Representatives Patricia Schroeder (D-Colo.) and James M. Hanley (D-N.Y.), and the administration felt it was better to devote its energies to other battles (\#3, 21-23; \#5, 4-6). The Senate Governmental Affairs Committee also sharply curbed veteran preference, in line with White House proposals. The veterans' lobby reacted, effectively organizing and targeting the House, arguing that changes to the policy meant reneging on a traditional agreement with those who risked their lives defending the country $(\# 16,4 ; \# 22$, 4). As a result, even members who supported curtailment of veteran preference did not wish to go on record as voting for it and asked the White House to call on their vote only if it was clear it would make the difference between winning and losing (\#2-3, 15; \#3, 16-17). ${ }^{31}$

As the above examples indicate, opponents of the CSRA created substantial debate and resistance when they dramatized desirable values of their own. Debate concentrated on aspects of the legislation that was easily linked to values that could be clearly dramatized, rather than on the parts of the bill that had greatest relevance for the regular workday of public employees. The appeal to values is nothing new in an area where the values of public administration have always held greater comprehensibility and appeal than its actual details. A potential effect is to create a significant disjunction between the values policymakers focus on and the details of reform. Stephen Skrowronek notes that the Pendleton Act itself "yielded little more than symbolism for the bureaucratic reconstruction that lay at the heart of the reform leaders' concerns." 33

The implication is that long, complex, and dry public management legislation may not achieve the goals that the rhetoric of associated values advertises. Grasping for values as a guide to understanding the legislation, even knowledgeable proponents may not understand the implementation outcomes of the actual legislative text. This becomes even more likely for compromise language that reflects a divergence of views. Sugarman recalls how the loose ends in the bill were finally tied in conference (between 18 September and 5 October 1978): "The final act was really played out, you know, in back room negotiations between Bill Ford and Senator [Jacob] Javits. They came back with language that they had agreed on, and Javits explained it his way and Ford explained it his way. It remains for us to figure out which way was the one they really agreed to; not us so much as the Federal Labor Relations Authority" (\#30, 23).

Both the White House and Ken Blaylock, head of the American Federation of Government Employees (AFGE), claimed to have won their version of the labor-relations title. Members of the ad- 
ministration claimed to have brought the bill back to what they wanted through the strategy of "keeping it fuzzy," watering down the labor-relations title as the bill moved from committee to the House floor and to conference committee. But "keeping it fuzzy" also meant using ambivalent statutory language to mask the differences between diverging views, allowing both sides to claim victory. ${ }^{34}$ When asked if he thought he had won on civil service reform, Blaylock says: "Oh yes, there's no doubt about it, and if I had the decision to make again today I'd make the same decision" $(\# 1,31)$. Blaylock is supported by management consultant Bernard Gladieux. A longtime flexibility advocate, Gladieux testified before Congress in support of the CSRA. However, he withdrew his support when the labor-relations text was introduced.

Anyway I became quite skeptical whether the reform which purported to strengthen management was going to bring the anticipated result. Again, I felt that it had been watered down so much that the outcome was very dubious-though agreeing to many things in the bill which I thought was good like the Senior Executive Service-all of us have always been for that. I was also in favor of the merit pay provisions in the place of the automatic promotion practices and all that kind of thing. But on the big issue of management control and management prerogatives, I thought the reform act could prove to be retrogressive. To put it very bluntly, I thought Scotty and the White House sold out to the unions or were naive in their perceptions of labor union politics. I don't think it's ever quite come out yet how big the unions won in this battle. Only time will tell how seriously Title VII is going to impair the achievement of the kind of management control that so many of us felt was so necessary over the years. $(\# 8,8)$

Blaylock's view is also lent credibility by the fact that he was consulted on the legislative language that was sent to Congress. He kept a close eye on the text of the CSRA as it was amended, to the extent that he did not object to the antibureaucracy rhetoric because he did not think it reflected what was actually in the bill:

As long as I knew what was in that Act, I personally was comfortable. In fact, I intentionally let the issue ride, that "we're making it easier to fire federal employees." That's what scared 
the hell out of the people.... Many Congressmen went home and told their constituents in November that "we voted for civil service reform, we're going to make it easier to fire those complacent workers," and all this crap, but everybody now is seeing what's actually in the law.... Now I can probably recite that damn law to you chapter and verse, because every word that went there meant something ... and we couldn't let one line slip by. $(\# 1,15)$

Different sides read the CSRA as providing different outcomes. Ultimately, all sides were guessing, based on their knowledge of the legislation and their assumptions about how it would actually be implemented. The passing of time and contemporary perspectives on the civil service system offers support for Blaylock's guess. Flexibility advocates argue that Title VII is a limit on management flexibility, and the type of personnel complaints made in 1978—about a lack of managerial control on hiring, pay, transfer, or adverse action against workers-remain.

\section{Links to Contemporary Public Management Debate}

Given that the CSRA pulled in different directions, it is not altogether surprising that its implementation led to mixed and sometimes unanticipated results and ultimately failed to live up to the expectations of flexibility advocates. The SES certainly failed to live up to expectations. It started well; almost all senior managers volunteered to join what was advertised as a high-risk/high-reward system. However, the OPM quickly reduced the size of performance bonuses available, creating a perception that the high-reward side of the bargain would not be met. The high-risk element did not appear to materialize in terms of firing, but it existed through the possibility of job reassignments for punitive purposes. The Reagan administration, under OPM Director Donald Devine, was criticized heavily for using reassignment to ensure ideological consistency of key employees. Years later, Dwight Ink, director of the PMP, wrote: "We know of cases of abuse in OPM and various agencies reminiscent of the Watergate days. However, there is no oversight capacity today to tell us whether there are only a few such cases or if the problem is more endemic. But the fact that these abuses occur without remedial action indicates my assurance to Congress that the 
CSRA safeguards would be effective were overly optimistic." 35 The partisan use of civil service reform clearly echoes Martin Shefter's analysis of the administrative state, which portrays use of bureaucratic institutional rules as politics by other means. ${ }^{36}$

The SES did not produce the mobility across function necessary to create a cadre of generalist managers, similar to the British model that inspired the SES. ${ }^{37}$ Specialized expertise, rather than general management potential, remained the basis for promotion into the SES. Unsurprisingly, then, such specialists chose not to move to areas beyond their expertise. Mobility was further discouraged by an increasing tendency for agencies to use whatever flexibility they could to develop agency-specific personnel systems. In practice, individual performance appraisals and pay-for-performance also floundered, due to evaluation grade inflation. For instance, every year from 1991 to 1996, at every level of the federal employment, less than one percent of employees received anything under a "fully successful" rating. ${ }^{38}$ The realization that pay-for-performance was not achieving its goals led to its abandonment for mid-level employees during the first Bush presidency.

Flexibility advocates argued that the CSRA was essentially an incremental law that did not create a performance framework for personnel. In particular, the CSRA failed to deliver the managerial flexibility required to break a culture of compliance that was argued to typify the public service. These arguments became even more persistent in the 1980s and 1990s, adopted in the guise of what would be referred to as "New Public Management" principles. During this time, other countries radically restructured civil service systems, in some cases giving public managers personnel flexibility equivalent to private-sector counterparts. ${ }^{39}$

Both the Clinton and George W. Bush administrations proposed that the CSRA had the right idea in terms of flexibility but failed to go far enough. The architects of the CSRA saw the OPM as a central guide that would facilitate decentralization of personnel authority, and under Carter the OPM encouraged decentralization. ${ }^{40}$ However, under Reagan, the OPM began a pattern of centralization of personnel policy by creating additional rules. This pattern was not reversed until the NPR, led by Vice President Al Gore. The NPR did two things. First, it pushed the OPM to cut nonlegislative rules, leading to a White House ceremony where OPM's massive Federal Personnel Manual was eliminated. Next, the White House targeted the OPM itself, judging that a smaller organization would 
be less able to create new rules. During the Clinton administration, the number of employees in the OPM was cut in half. ${ }^{41}$

The Clinton administration did offer legislation to change government-wide personnel policy, but it failed to devote much political energy to it and Congress rebuffed its efforts. Congress did, however, pass legislation granting increased flexibility in the name of performance for the Federal Aviation Administration and the Internal Revenue Service. The NPR therefore sought alternatives to government-wide legislation to further managerial flexibility, using executive orders to reduce administrative rules and provide waivers from rules.

The Clinton administration also actively used demonstration project authority created by the CSRA. Experimentation allowed under Title VI provides one of the unanticipated consequences of the CSRA. Initially, demonstration projects worked as intended: provisions of flexibility were made sparingly_only seven from 1978 to 1993 - with the intention that the resulting lessons would inform civil service policy. Innovations at the Navy's China Lake and the Air Force's Pacer Share projects informed debates about pay policy. However, under the pro-flexibility Clinton administration, the waivers from personnel law that demonstration projects provided became an end in itself, rather than a means to foster learning from experiments. Title VI authority was used as another means of increasing agency flexibility and bypassing government-wide personnel rules, and was used much more frequently-fifteen times under Clinton.

George W. Bush also argued that Congress should increase managerial flexibility in the name of performance. When early legislative efforts to change government-wide rules stalled, the White House attached flexibility provisions to the Homeland Security Act of 2002. Rearticulating the protection doctrine, Senate Democrats refused to pass the bill and sought to restrict the President's ability to limit union membership in cases where national security was a concern, a power originally created under Title VII of the CSRA. Bush threatened to veto the legislation if the flexibility provisions were compromised. Months of impasse were broken when the Republicans regained the Senate and quickly passed the President's preferred version of the bill. The Homeland Security Act provides the Secretary a largely unchecked authority to "establish, and from time to time adjust, a human resources management system for some or all of the organizational units of the Department of Homeland Security," creating a system that should be "flexible," "contemporary," and 
grounded in the public employment principles of merit and fitness. The President retains the power to waive the rights of unions to organize if he judges that homeland security would be compromised, but he must give ten days notice to Congress. The Act includes additional provisions to foster managerial flexibility not just for the Department of Homeland Security but for the entire government, including enhanced agency freedom from traditional civil service rules in employee recruitment and retention.

\section{Conclusion}

Later assessments would come to the conclusion that the CSRA was ultimately an incremental reform or, perhaps more incisively, a reform that retained a series of contradictory messages. ${ }^{42}$ This article helps explain why. The CSRA was the outcome of the new flexibility doctrine struggling to overcome the traditional protection doctrine. It only partially succeeded, in large part because by 1978 the civil service was an institutional anchor that could limit changes in direction. Whereas once political parties acted as political institutions that shaped the original protection doctrine in the Pendleton Act, the creation of the civil service system gave life to another institutional force that acted to restrict future change.

Since the Pendleton Act, existing rules had proven difficult to change, directing reformers to seek incremental reform. Public service unions proved fierce defenders of the status quo, particularly in relation to the statutory job protections that public employees enjoyed. The fact that the CSRA fostered any change in the civil service system, especially after the personnel abuses of the Nixon era, is remarkable enough. While the pace of reform may strike flexibility advocates as glacial, actual changes did occur, and subsequent debate was increasingly dominated by the flexibility doctrine. The passage of the Homeland Security Act represents another incremental but significant step in the direction of flexibility. It also marked a significantly more partisan tone to the debate. Clinton and Gore's National Performance Review embraced the idea of flexibility, but not to the point of eliminating the protections valued by their traditional union constituency. Republicans lacked any such ambivalence, seeing a reduction of civil service protections as the logical application of the flexibility doctrine. 
At its heart the CSRA was a debate about two different public sectors. The most marked advocates of either doctrine, those who rejected the arguments of the other, were engaged in a battle of ideas. But legislative outcomes ultimately reflect compromise between groups, and between new policy suggestions and the existing policy framework. The compromises made in passing the CSRA reflected a middle ground, made up of those who believed it was possible to retain traditional civil service protections while making the system more performance-driven (\#2-2, 14-16; \#17,4). What distinguishes Campbell and his fellow reformers from later flexibility advocates is the belief in the value of protection, and a willingness to craft reform solutions that simultaneously sought to increase flexibility and protection.

That public employment in the United States reflects a mix of apparently conflicting ideas is consistent with its history. ${ }^{43}$ This was, after all, a system that for a century had married and maintained a merit-based bureaucracy with the remnants of the spoils system. But it does mean that the U.S. system lacks a coherent personnel framework, with clear assumptions about the appropriate protection and powers of those who undertake public work. Instead, current public management debate centers on how the tensions inherent in the system relate to one another-how rules intended to promote performance and responsiveness undercut neutral competence and vice versa. The incremental and piecemeal nature of reform since 1978, and the divergence of perspectives between the two doctrines, suggests that this situation is unlikely to change soon.

\section{The Bush School of Government and Public Service Texas AEM University}

\section{Acknowledgments}

I am indebted to Patricia Ingraham, Rogan Kersh, Suzanne Mettler, Pamela Herd, and three anonymous reviewers for their insightful comments on earlier versions of this article. I would also like to thank the Alan K. Campbell Public Affairs Institute at Syracuse University for access to the interview transcripts that formed the core of this analysis. 


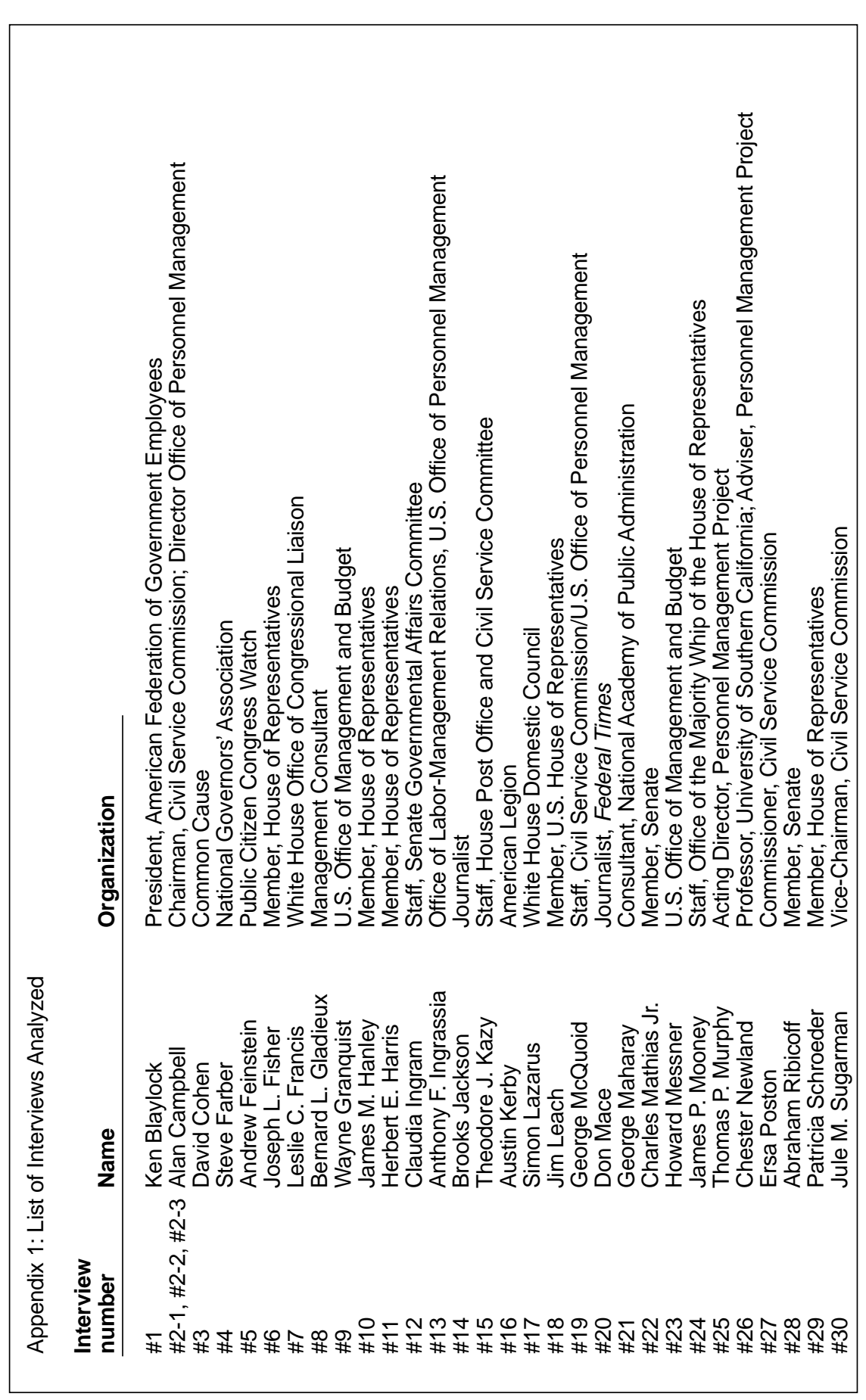




\section{Notes}

1. James P. Pfiffner and Douglas A. Brook, eds., The Future of Merit: Twenty Years After the Civil Service Reform Act (Washington, D.C., 2000). The authors in Pfiffner and Brook are primarily interested in reassessing the CSRA in terms of its impact from a variety of contemporary perspectives, such as performance and accountability and globalization and the changing state. By contrast, this article undertakes original research to reassess the CSRA from the perspective of its framers, before linking to the contemporary public management debate.

2. For a discussion of administrative doctrines, see Christopher Hood and Michael Jackson, Administrative Ar gument (Hanover, N.H., 1991), and Christopher Hood and Michael Jackson, "Key for Locks in Administrative Argument," Administration and Society 25 (1994): 467-88.

3. National Performance Review, From Red Tapes to Results: Creating a Government that Works Better and Costs Less (Washington, D.C., 1993).

4. U.S. Office of Management and Budget, The President's Management Agenda (Washington, D.C., 2001).

5. An example of the contemporary debate analyzing these tensions and featuring high-level practitioners, academics, and management experts can be found in Patricia W. Ingraham, Sally C. Selden, and Donald P. Moynihan, "People and Performance: Challenges for the Future Public Service-the Report from the Wye River Conference," Public Administration Review 60 (January-February 1993): 5460 .

6. James R. Thompson, "The Clinton Reforms and the Administrative Ascendancy of Congress," American Review of Public Administration 31 (September 2001): 249-72.

7. On unanticipated consequences, see Michael Nelson, "A Short Ironic History of American National Bureaucracy," Journal of Politics 44 (1982): 747-78. On the fight for political control, see Martin Shefter, "Party, Bureaucracy, and Political Change in the United States," in Louis Maisel and Joseph Cooper, eds., Political Parties: Development and Decay (Beverly Hills, 1978). Stephen Skrowronek's analysis of the origins of the administrative state covers these issues and documents the closely-bound nature of administrative reform and politics; Skrowronek, Building a New American State (New York, 1982).

8. B. Guy Peters, Institutional Theory in Political Science: The New Institutionalism (London, 2000).

9. Earlier exemplary works on the CSRA can be found in Patricia W. Ingraham, and Carolyn Ban, eds., Legislating Bureaucratic Change: The Civil Service Reform Act of 1978 (Albany, N.Y., 1984), and Patricia W. Ingraham and David H. Rosenbloom, eds., The Promise and Paradox of Civil Ser vice Reform (Pittsburgh, 1992). This article adds to the theoretical perspectives presented in these volumes by tracing the protection-flexibility dichotomy that dominates current public management debate to its first full expression in the CSRA.

10. Exemplary works include Richard E. Cohen, Washington at Work: Back Rooms and Clean Air (Boston, 1995); Haynes Johnson and David Broder, The System: The American Way of Politics at the Breaking Point (Boston, 1996); David Maraniss and Michael Weisskopf, Tell Newt to Shut Up! (New York, 1996); Ted Marmor, The Politics of Medicare, 2d ed. (New York, 2000); Eric Redman (1973), The Dance of Legislation (New York, 1973). The works cited also highlight the high frequency of journalists in undertaking these analyses.

11. QSR NUDIST allows analysis of data using a hierarchical coding system. The software is flexible enough to allow both inductive and deductive coding and modification of the coding structure to facilitate the dialogue of themes, concepts, 
and evidence. As codes are established, the definition of what each code means may be attached, as well as memos on the emerging trends that are associated with a particular code. The software is therefore ideal for the type of research undertaken here. It allows for the creation of broad codes that facilitate descriptive information of the legislative process, deductive codes based on the legislative outcomes, and inductively created codes based on the case evidence. For more information, see Celia Gahan and Mike Hannibal, Doing Qualitative Research Using QSR Nudist (London, 1998).

12. Skrowronek, Building a New American State.

13. For a Progressive perspective that would strongly influence public administration scholarship, see Woodrow Wilson, "The Study of Administration," Political Science Quarterly 2 (1887): 207-22. Dwight Waldo's history of the administrative state notes that the Progressives pursued not only competent management but also moral government; Waldo, The Administrative State: A Study in the Political Theor y of American Public Administration (New York, 1948).

14. By the early twentieth century a number of public management principles had developed to guide the practitioner. Herbert Simon recast such principles as a series of mutually contradictory proverbs whose usefulness was contingent on the situation; Simon, "The Proverbs of Administration," Public Administration Review 6 (Winter 1946): 53-47. However, Simon's attack on the administrative orthodoxy did not extend directly to the protection doctrine that underpinned the civil service. Although the empirically-based social science approach advocated by Simon gained strength, public management policymaking retains a preference for persuasively argued success stories that lend themselves to management principles. A good example is the success of the David E. Osborne and Ted Gaebler book, Reinventing Government: How the Entr epreneurial Government Is Transforming the Public Sector (New York, 1992). The book became a best-seller, strongly influencing government reform at state, local, and particularly the federal level through the National Performance Review.

15. Patricia W. Ingraham, The Foundation of Merit (Baltimore, 1995), especially chapter 3.

16. Vincent Ostrom, The Intellectual Crisis in Public Administration, $2 \mathrm{~d}$ ed. (Tuscaloosa, 1989), 7-8. Ostrom's review of public-administration intellectual history presents a malaise due to a continued failure to move away from traditional ways of thinking about administration. His solution was to embrace public-choice economics. Ostrom emphasizes the decentralization aspects of public choice. Other public-choice economists would attack the internal workings of the public sector, including civil service rules, as inefficient and nondemocratic. While these arguments were made around the time of the CSRA, the influence of public-choice ideas does not appear in any of the interviews of key actors or in documentation of the PMP. Instead, public-choice economics proved to have a greater influence on civil service reform overseas, in countries such as the U.K., New Zealand, and Australia. On the role of public choice and adoption of reform, see Jonathan Boston, "The Theoretical Underpinnings of Public Sector Restructuring in New Zealand," in Jonathan Boston, John Martin, June Pallot, and Pat Walsh, eds., Reshaping the State (Auckland, 1991). In reviewing the leading contemporary public management doctrine, known as the New Public Management, Peter Aucoin argues that it is a mixture of public-choice arguments and managerial arguments derived from private-sector organizations; Peter Aucoin, "Administrative Reform in Public Management: Paradigms, Principles, Paradoxes, and Pendulums," Governance 3 (1990): 115-37. This article demonstrates the influence of managerial arguments in 1978 and the relative absence of public-choice arguments. The success of Osborne and Gaebler's Reinventing Gover nment and the use of private organizations as a model by both the Clinton and the George W. Bush administrations suggests the continued 
dominance of managerial arguments in U.S. contemporary public management debate.

17. Chester Newland, "The Politics of Transition," in James P. Pfiffner and Douglas A. Brook eds., The Future of Merit (Washington, D.C., 2000). Richard Nathan, a political appointee under Nixon, recounts the experience in The Plot That Failed: Nixon and the Administrative Pr esidency (New York, 1975).

18. Common Cause and other public-interest groups had been actively involved in researching and exposing what they saw as the politicization of the merit system under Nixon. See Newland, "The Politics of Transition," 206-8.

19. The proposals that the president sent to Congress in March 1978 reflected an even stronger flexibility perspective than the final legislative outcomes described in Table 1, in large part because the original proposal did not include a labor-relations title sought by public employee unions. However, it became clear that the unions would succeed in having a title added, and the administration sent laborrelations language to Congress in May, which, after some significant revision in the House, would become Title VII.

20. Patricia W. Ingraham and Donald P. Moynihan, "Evolving Dimensions of Performance from the CSRA to the Present," in James P. Pfiffner and Douglas A. Brook, eds., The Future of Merit (Washington, D.C., 2000).

21. Frederick W. Taylor argued for a "scientific management" based on the most efficient use of resources for a given task in The Principles of Scientific Management (New York, 1919). For discussion of management principles, see Luther Gulick and Lyndall Urwick, eds., Papers on the Science of Administration (New York, 1937). A related proposal for reorganizing the public sector can be found in U.S. President's Committee on Administrative Management, Report with Special Studies (Washington, D.C., 1937).

22. David Brian Robertson, "Introduction: Loss of Confidence and Policy Change in the 1970s," Journal of Policy History 10 (1998): 1-18. The CSRA case reflects the importance of public-interest groups in the prominence of Common Cause in policy decisions.

23. Sidney Milkis, "Remaking Government Institutions in the 1970s: Participatory Democracy and the Triumph of Administrative Politics," Journal of Policy History 10 (1998): 51-74.

24. While a negative attitude toward bureaucracy characterized both Carter's presidential campaign and the public campaign for the CSRA, Carter himself did not have a strongly negative view of public employees. Howard Messner of the OMB recalls this in a meeting with the president: "The President expressed his awareness of growing public attitudes but stressed that he did not want to develop a posture that pitted him against 'his fellow workers.' To do this, he stated, would undermine his efforts to achieve substantial programmatic changes. In other words, if the employees felt that they didn't like him, and he was alienated from them, it wouldn't help him change the government" $(\# 23,21)$.

25. Hood and Jackson, Administrative Argument. Such a style of doctrinal-based argumentation continues to recur in public management debate, despite an increased focus on social scientific research in public administration.

26. Frederick Thayer makes a similar point, suggesting that while the pay-forperformance aspect of the CSRA was linked to expectancy theory, the evidence supporting such theory was weak, and the CSRA was relying on a "dubious mythology" that did not match public-sector needs; Thayer, "The President's Management 'Reform': Theory X Triumphant," Public Administration Review 48 (July-August 1978): 311. Later empirical research on pay-for-performance systems in the public sector found them to be largely unsuccessful: J. Edward Kellough and Haoran Lu, "The Paradox of Merit Pay in the Public Sector: Persistence of a Problematic Procedure," Review of Public Personnel Administration 13, no. 2 (Spring 1993): 45- 
64; Patricia W. Ingraham, "Of Pigs in Pokes and Policy Diffusion: Another Look at Pay-for-Performance," Public Administration Review 53 (July-August 1993): 34856.

27. The lack of strong social science research, despite efforts to create the appearance of scientific knowledge, may be closer to the rule rather than exception in public management policymaking. Roberts notes a similar pattern with the 1937 Brownlow Committee, tasked with recommending administrative reforms. Although social science was not well developed in universities at this point, especially in public administration, "the committee not only aspired to conduct scientific research but they also went out of their way to make a point of showing that they had conducted scientific research." Alasdair Roberts, "Why the Brownlow Committee Failed: Neutrality and Partisanship in the Early Years of Public Administration," Administration and Society 28 (1996): 31.

28. Campbell made the comment during remarks at the Symposium on Civil Service Reform, State University of New York at Binghamton, October 1981, quoted in Ingraham, The Foundation of Merit, 82.

29. From an interest-group perspective, Mancur Olson examines the difficulties larger groups encounter in seeking public goods, and the relative success of smaller groups in organizing; Olson, The Logic of Collective Action (Cambridge, 1971). From a legislative viewpoint, R. Douglas Arnold offers a formal model that distinguishes the costs and benefits of general public versus specific group perspectives on policies and how they affect congressional preferences; Arnold, The Logic of Congressional Action (New Haven, 1990).

30. Both senators had developed a series of amendments intended to avert what they saw as politicization of the career civil service. Several negotiations with the administration failed to produce a compromise until the senators and Carter met directly. Once the broad outlines of a consensus were reached, Carter ordered staff from both sides to remain in the White House until specific compromise legislative language was crafted. The amendments served to limit the power of the OPM, classify some positions as career-reserved, and strengthen the oversight powers of the MSPB.

31. This observation fits with well-established assumptions about member preferences to establish an acceptable voting record to further the prospect of reelection, especially in issues where certain constituencies, such as the American Legion, follow roll-call activity closely. R. Douglas Arnold, Congress and the Bureaucracy: A Theory of Influence (New Haven, 1979), 26-28.

32. The importance of values and symbols in politics has been well recounted by Murray Edelman, The Symbolic Uses of Politics (Chicago, 1964).

33. Skrowronek, Building a New American State, 68.

34. Campbell notes that "we made some of the language somewhat more fuzzy than I had hoped it would be, and we're now paying the price for that as these matters are negotiated out and the Federal Labor Relations Authority is going to have to make a lot of decisions on matters that aren't clear" $(\# 2-1,24)$.

35. Dwight Ink, "What Was Behind the 1978 Civil Service Reform?" in James P. Pfiffner and Douglas A. Brook, eds., The Future of Merit (Washington, D.C., 2000), 54.

36. Shefter, "Party, Bureaucracy, and Political Change in the United States."

37. Mark W. Huddleston and William W. Boyer, The Higher Civil Service in the United States: Quest for Reform (Pittsburgh, 1996).

38. U.S. Office of Personnel Management, The Fact Book, Federal Civilian Workforce Statistics, 1998 Edition (Washington, D.C., 1998), 68.

39. For a summary of the New Public Management, see Michael Barzelay, Explaining the New Public Management: Improving Research and Policy Dialogue (Berke- 
ley and Los Angeles, 2001). See especially chapter 4 for an analysis of contemporary administrative doctrine and desirable standards for administrative argument.

40. Ink, "What Was Behind the 1978 Civil Service Reform?" 44.

41. James R. Thompson, "Devising Administrative Reform That Works: The Example of the Reinvention Lab Program," Public Administration Review 59 (JulyAugust 1999): 283-93.

42. Ingraham and Ban, Legislating Bureaucratic Reform, Introduction.

43. The propensity of the public employment system to reflect a mixture of contradictory goals is not a new idea, and in fact it might be considered more the norm than the exception. Herbert Kaufman highlighted this tendency, noting how cycles of reforms pursue the seemingly mutually exclusive goals of representativeness, neutral competence, and leadership; Kaufman, "Emerging Conflicts in the Doctrines of Public Administration," American Political Science Review 50 (December 1956): 1057-73. 